BBA 3854

\title{
HYDROCARBON OXIDATION BY A BACTERIAL ENZYME SYSTEM
}

\section{PRODUCTS OF OCTANE OXIDATION}

\author{
J AMES N. BAPTIST*, ROBERT K. GHOLSON*" AND MINOR J. COON \\ Department of Biological Chemistry, Medical School, The Lniersity of Michigan. \\ iim -ivibu, . wich. (L.S.A.) \\ (Received July 1 7 th, 1962)
}

\section{SUMMARY}

A Pseudomonad which grows on hexane as sole carbon source was isolated from soil by enrichment-cultuze technique. Cell-iree, soluble enzyme preparations of the organism catalyze the oxidation of ${ }^{14} \mathrm{C}$-labeled octane to radioactive octanoic acid.

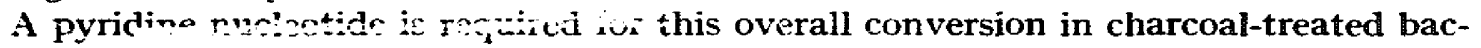
terial extracts. $n$-Octanol and octaldehyde were identified as products of octane oxidation and the presence in the enzyme preparations of DPN-dependent dehydrogenases acting on octanol and octaldehyde was demonstrated.

\section{IXTRODUCTION}

The ability of a variety of aerobic microorganisms to utilize paraffins and other hydrocarbons has been abundantly documented, as described in comprehensive reviewsi-3. Primary oxidation products having the same carbon skeleton as the hydrocarbon substrates have been identified in only a few cases, however, and the discussion of such examples will be limited to the aliphatic alkanes. Methane-utilizing bacteria apparently produce methanol, formaldehyde and formate ${ }^{4,5}$ and also have been shown to convert ethane to acetaldekyde and acetate, propane to propionate and acetone, and butane to butyrate and butanone ${ }^{6}$. STEWART et al. ${ }^{7}$ carefully identified cetyi palmitate as a product of hexadecane metabolism in cultures of a Gram-negative coccus; atmospheric oxygen participates directly in the process as shown by ${ }^{18} \mathrm{O}$ incorporation into the wax to the extent of $75 \%$. They interpreted their data to indicate that cetyl palmitate is formed from cetyl alcohol and palmitate, and I-hexadecyl hydroperoxide was suggested as a possible intermediate. STEWART AND KALLIO ${ }^{8}$ have observed that cultures of the coccus also utilize other long-chain hydrocarbons to produce waxes in which the alcohol has the corresponding carbon skeleton but the acid moiety is palmitate, or in one case, stearate.

A soluble enzyme system capable of oxidizing octane to octanoate was described in a preliminary report by BAPTIST AND $\operatorname{COON}^{\circ}$ and is the subject of the present paper.

- Postdoctoral Fellow, Damon Runyon Memorial Furd. Present address: W. R. Grace and Co., Clarksvilie, Ma. (U.S.A.).

$\rightarrow$ Postdoctoral Fellow, National Heart Institute, Lnited States Public Health Service. F'resent address: Department of Medical Chemistry, Kyoto University, Kyoto (Japan). 
The enzyme system, obtained from a soil Pseudomonad grown on hexane as sole carbon source, yields $n$-octanol and octaldehyde as intermediate products and contains DPN-dependent dehydrogenases acting on these compounds as well as the enzyme(s) providing the initial oxidative attack on the hydrocarbon. To our knowledge there have been no other descriptions of cell-free enzyme preparations attacking aliphatic alkanes other than the report by SENEZ AND AZOULAY 10,11 that cell-free extracts of a Pseudomonad which oxidizes heptane to heptanoate" catalyze the "dehydrogenation" of paraffins. Spectrophotometric evidence was presented by these investigators for the reduction of DPN or pyocyanin in the extracts under anaerobic conditions, but evidence for the formation of the postulated olefin or other oxidation product in ceil-free extracts was not provided.

\section{MATERIALS AND METHODS}

\section{Isolation and culture of bacterial strain}

A bacterium which grows on technical grade $\boldsymbol{n}$-hexane as carbon source was isolated from mixed soil samples by enrichment culture technique. The organism has been tentatively identified by Dr. J. B. Davis of the Magnolia Petroleum Co. as a strain of Pseudomonas oleovorans, a bacterium previously isolated from machine shop cutting oil and described by LEE AND CHANDLER ${ }^{13}$. Our strain, which is different from the $P$. oleovorans obtainable from the American Type Culture Collection, also grows on $n$-heptane, $n$-octane and $n$-nonane and weakly on $n$-pentane, but not on cyclohexane or methylbutane. The organism grows well on L-leucine as sole carbon source, but enzyme extracts prepared from such cultures, though rich in $\beta$-methylcrotonyl carboxylase ${ }^{14}$, are apparently devoid of the hydrocarbon-oxidizing system.

The organism was grown in 3-1 Fernbach flasks containing a buffer-salt solution

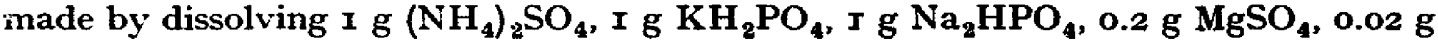
$\mathrm{CaCl}_{2}$, and o.or $\mathrm{g} \mathrm{FeCl}_{3}$ in I $\mathrm{l}$ of water. Hexane was supplied in the gas phase by placing a small open container of hexane inside the culture flask. The flask was inoculated with Io $\mathrm{ml}$ of a culture previously grown in the same manner and was allowed to stand without agitation 3-4 days at room temperature. Upon centrifugation $1-2$ g of cells, wet weight, were obtained per flask. Aeration or the addition of yeast extract to the medium $(0.2 \mathrm{~g} / \mathrm{l})$ gave faster growth but did not result in an increased content of hydrocarbon-oxidizing enzymes as judged by the conversion of $\left[\mathrm{I}^{14} \mathrm{C}\right]$ octane to radioactive octanoate in cell-free extracts.

\section{Preparation of hydrocarbon-oxidizing enzyme system}

The packed cells were dispersed in 2 vol. of $0.1 \mathrm{M}$ potassium phosphate buffer ( $\mathrm{pH} 7.8$ ) and submitted to a pressure drop from $15000 \mathrm{lb} / \mathrm{in}^{2}$ to atmospheric pressure with use of a French pressure cell. Alternatively, the packed cells were ground for $3 \mathrm{~min}$ at $0^{\circ}$ in a mortar with twice their weight of alumina (Alcoa A-305), and the resulting paste was dispersed in a volume of phosphate buffer twice the weight of the wet cells. Broken-cell preparations made in either of these ways were kept for $20 \mathrm{~min}$ at $0^{\circ}$ and then centrifuged at $20000 \times \mathrm{g}$ for $20 \mathrm{~min}$. The supernatant solution, containing the hydrocarbon-oxidizing enzyme system, was kept frozen until used. Typical extracts contained about $40 \mathrm{mg}$ protein $/ \mathrm{ml}$. In the crude extract, activity 
was retained on prolonged the frozen state. After partial purification the system is less stable, but pattlis puroted by the addition of ascorbate.

\section{Estimation of enzyme actizizy}

The overall conversiom aff octane to radioactive octanoate was taken as a measure of the activity wf the foryme system. The following components were incubated for $I \mathrm{~h}$ at $25^{\circ}$ in $\mathrm{si}$ frrall urlime of $1.0 \mathrm{ml}: 70 \mu$ moles putassium phosphate

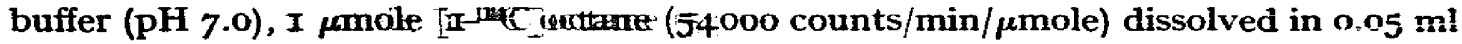
ethanol, $5^{\circ} \mu$ moles nicutimaniide, and the bacterial enzyme preparation to be tested. The mixture was then acidififed wüth no; $\%$ sulfuric acid (about $0.25 \mathrm{ml}$ ) and extracted by shaking with ether, and the ethen layer was then extrected with $0.5 \mathrm{ml}$ of dilute KOH solution. An aliquot df the alkaline solution containing radioactive octanoate was dried on a planchat and unuted. The counts reported have been corrected to zero thickness. In typical expmiment from 8 to $32 \%$ of the octant was converted to octanoate in the presenue (yif ande bacterial extract (ro $\mathrm{mg}$ protein) under the conditions described. This prrutudime provides a rough measure of the activity of the overall hydrocarbon-axifiëing entanme system. For further studies a more accurate method for estimating brofh ruttarnll and octanoate has been devised, as will be described in the second prperr off this series.

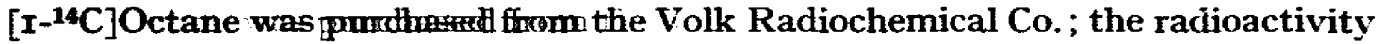
was determined in a Tiquid acintillltiön counter and expressed as the count expected in an end-window Geiger commther ffom: the known efficiency of both instruments. This preparation contained mo naffirmative acidic materials, for no significant amount of radioactivity was extracteible into aqueous alkali. Impurities readily oxidizable to acids were also langely or acidic permanganate gance milk traces of ${ }^{14} \mathrm{C}$-labeled acidic materials.

Pyridine nuclectides wene obttained commercially. Technical grade $n$-hexane was obtained from Phillips Pertarm $\mathbb{C}_{3}$. The protein concentration of crude enzyme solutions was estimated bay the porcediure of Lowny et al. ${ }^{15}$, whereas that of purified preparations was estimatted the method of WARBURg AND ChRISTIANIB.

\section{RESULTS}

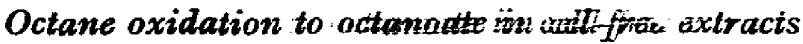

In preliminary expeniment ift was found that a suspension of whole bacterial cells readily oxidized [Iradioactive substance extraction from acid solution and in turn extracter from ether into aqueous altali. Thï organic acid was identified as octanoic by paper and column chromatograping.

The $R_{F}$ values of the urrlumowm acid on paper chromatograms in several solvent systems were those expedted (off a sathmated fatty acid having more than 6 and less than 9 carbon atoms. A mprile (athum rzoo total counts) was then shown to migrate with carrier octanuic uäd um decending paper chromatography in heptane-

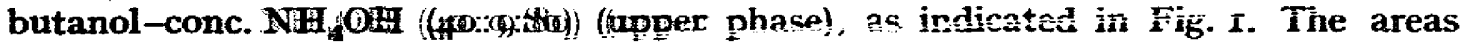
indicated by broken lines wens: aut out, placed on planchets and counted, and the 
radioactivity was found to coincide with the octanoate area located by spraying with bromcresol green.

$\Lambda$ larger sample of the radioactive acid was further identificd by reversed phase chromatography on a column of siliconized Super-cel by the general method of HowARD AND MARTIN ${ }^{17}$ but with a different solvent system. A mixture of $160 \mathrm{ml}$ chloroform, $30 \mathrm{ml}$ Skellysolve $\mathrm{S}, 240 \mathrm{ml}$ water, and $400 \mathrm{ml}$ methanol was allowed to separate into two phases. For preparation of the column, $6 \mathrm{~g}$ of hydrophobic kieselguhr (Hyflo Super-cel treated with dichlorodimethyl silane) were mixed with
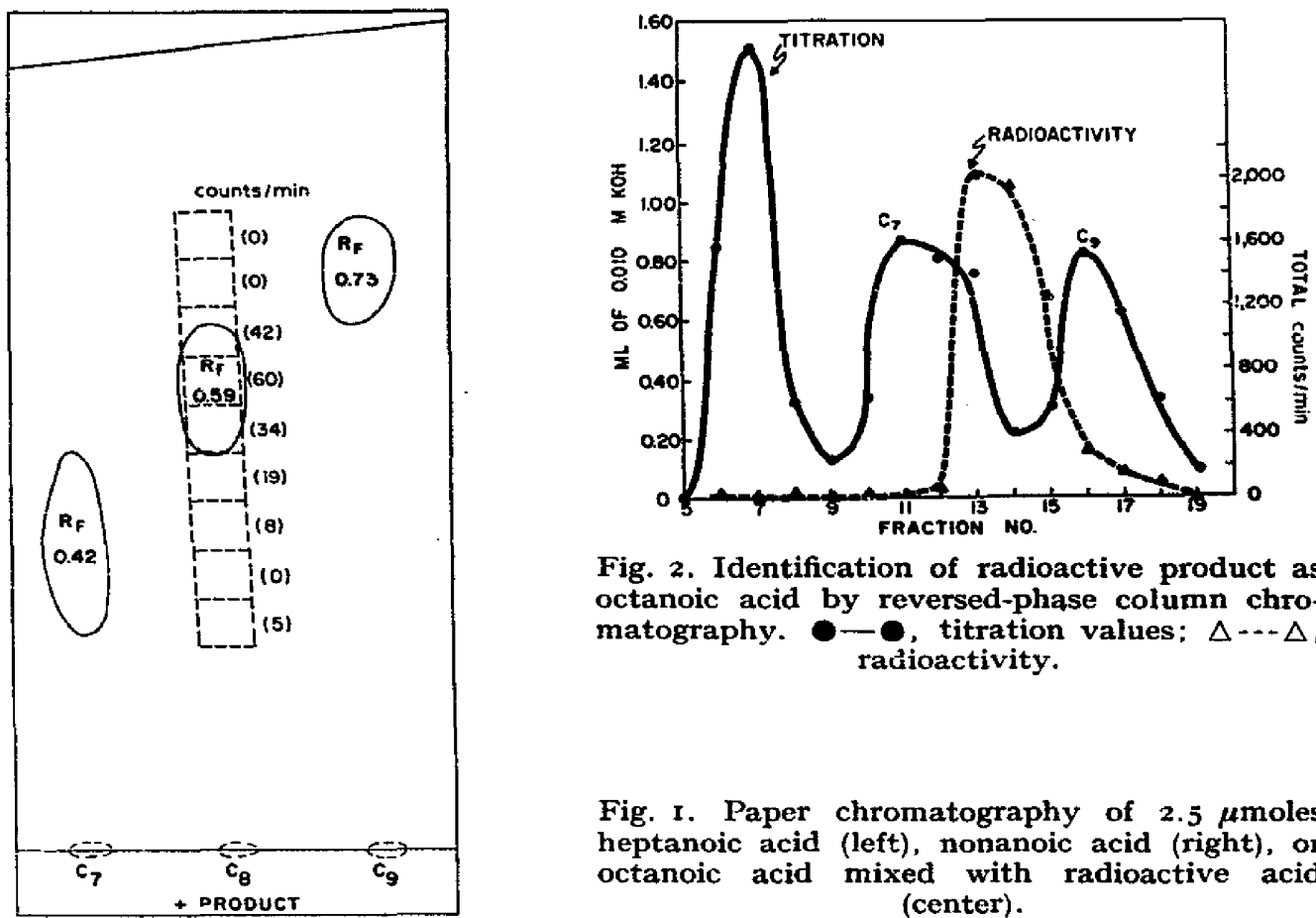

Fig. 2. Identification of radioactive product as octanoic acid by reversed-phase column chromatography. - titration values: $\Delta \cdots \Delta$, rauioactivity.

Fig. I. Paper chromatography of $2.5 \mu$ moles heptanoic acid (left), nonanoic acid (right), or octanoic acid mixed with radioactive acid (center).

$5 \mathrm{ml}$ of the lower (chloroform-rich) phase, some of the upper phase was then added, and the resulting slurry was transferred to a column II $\mathrm{mm}$ in diameter. The radioactive acid in $0.5 \mathrm{ml}$ of the upper phase was applied to the column and $2.5-\mathrm{ml}$ fractions were collected while more of the upper phase was added to the column. Radioactivity was found exclusively in tubes ro-I4. The contents were pooled and acidified with sulfuric acid, the radioactive acid was extracted into ether, and $4.8 \mathrm{mg}$ each of heptanoic and nonanoic acids were added. Ether was removed and the mixture was again submitted to column chromatography. As shown in Fig. 2, the unknown radioactive acid was located chiefly in fractions I3 and I4, following heptanoic and preceding nonanoic acid. More polar, non-radioactive acids were located in fractions 6-8. These acids, possibly citric acid cycle intermediates present in the crude, undialyzed extracts, have not been further characterized.

\section{Identification of octanol and octaldehyde as intermediate oxidation products}

The addition of a number of carbonyl-binding agents to the usual enzyme reaction mixtures containing $\left[{ }^{14} \mathrm{C}\right]$ octane was found to decrease the radioactivity appearing 
in octanoate, with the accumulation of a compound which could be converted to a radioactive 2,4 -dinitrophenylhydrazone readily soluble in $\mathrm{CCl}_{4}$. In the experiments shown in Table I a sufficient amount of hydroxylamine was employed to lower octanoate formation from ${ }^{14} \mathrm{C}$ octane to about one-tenth the usual value. Under these conditions both labeled octanol and octaldehyde accumulated and after the addition of carrier compounds could be isolated and recrystallized to constant radioactivity as the dinitrobenzoate and dinitrophenylhydrazone, respectively. The derivatives had melting points in good agreement with reported values.

\section{TABLE I}

ISOLATION OF RADIOACTIVE OCTANOL AND OCTALDEHYDE AS DERIVATIVES

For identification of octanol as an intermediate, $10 \mu$ moles $\left[1-{ }^{1+C}\right]$ octane, $500 \mu$ moles nicotinamide, $3.5 \mu$ moles TPNH, $500 \mu$ moles phosphate buffer (pH 7.0), 2 mmoles hydroxylamine (pH 7 ), and bacterial enzyme preparation (150 $\mathrm{mg}$ protein) were incubated $\mathrm{I} h$ at $25^{\circ}$; final volume, ro.o $\mathrm{ml}$. The mixture was then extracted with $50 \mathrm{ml}$ of ether containing $0.1 \mathrm{ml}$ of non-radioactive octanol. The ether layer was carefully evaporated, and $100 \mathrm{mg}$ of 3,5-dinitrobenzoyl chloride were added to the residue; the derivative was prepared and recrystallized from ethanol-water. For identification of octaldehyde as an intermediate, $2 \mu$ moles $\left[{ }^{13} \mathrm{C}\right.$ loctane (in ethanol), 100 moles nicotinamide, $0.7 \mu$ mole TPNH, $0.7 \mu$ mole DPN, $70 \mu$ moles potassium phosphate buffer $(\mathrm{pH} 7.0)$, $300 \mu$ moles hydroxylamine (pH 7 ) and bacterial enzyme preparation (30 $\mathrm{mg}$ protein) were incubated $\mathrm{I} \mathrm{h}$ at $25^{\circ}$; final volume, $2.0 \mathrm{ml}$. After precipitation of protein with trichloroacetic acid, 2,4-dinitrophenylhydrazine was added. The reaction mixture was extracted with $\mathrm{CCl}_{4}$ and to this extract $22 \mathrm{mg}$ of carrier octaldehyde dinitrophenylhydrazone were added. The compound was recrystallized from absolute alcohol by the addition of water to incipient turbidity.

\begin{tabular}{|c|c|c|}
\hline Trimess & $\begin{array}{c}\text { Cosmss/min/2.5 mg } \\
\text { octyl } \\
\text { dinutrobensoate }\end{array}$ & $\begin{array}{l}\text { Cownts/min/4.o } \\
\text { octaldehyde } \\
\text { dinitrophenylhydrazone }\end{array}$ \\
\hline I & 105 & 159 \\
\hline 2 & $\$ 6$ & 140 \\
\hline 3 & 93 & 135 \\
\hline 4 & 94 & $13^{\circ}$ \\
\hline 5 & $9 \mathrm{I}$ & I35 \\
\hline
\end{tabular}

Occurrence of octanol and octaldehyde dehydrogenases in bacterial enzyme preparations

In view of the above findings, attempts were made to establish the presence of octanol- and octaldehyde-oxidizing enzymes in the bacterial extracts. The occurrence of a pyridine nucleotide-dependent dehydrogenase acting on octanol was readily shown, and the enzyme partially purified as follows. A crude bacterial extract (ro ml) was placed in a 50-ml Erlenmeyer flask and heated with gentie shaking in a $5^{0}-55^{\circ}$ water bath for $15 \mathrm{~min}$. The preparation was immediately chilled, and the precipitate obtained upon centrifugation was discarded. Nucleic acids were partially removed by making the preparation $0.05 \mathrm{M}$ in $\mathrm{MnCl}_{2}$. The precipitate was removed and the supernatant solution was brought to $30 \%$ saturation in $\left(\mathrm{NH}_{4}\right)_{2} \mathrm{SO}_{4}$ by the addition of a saturated solution of the salt. The precipitate obtained upon centrifugation was discarded, and the supernatant solution was brought to $50 \%$ saturation. The resulting precipitate containing octanol dehydrogenase was dissolved in potassium phosphate buffer (pH 7.8). This preparation was essentially free of the enzyme(s) catalyzing the oxidation of octane to octanol. Spectrophotometric evidence for the action of this enzyme preparation is given in Fig. 3. DPN reduction is clearly dependent on the presence of octanol, and it is apparent that TPN can not substitute for DPN. 
The reaction is readily reversible as shown by DPNH oxidation in the presence of octaldehyde. (Fig. 4). When TPNH was substituted for DPNH, however, the rate was only slightly greater than in controls containing DPNH or TPNH but with octaldehyde omitted. Thus the reduction of the aldehyde appears to be DPNH-specific, as would be anticipated from the findings in Fig. 3 .

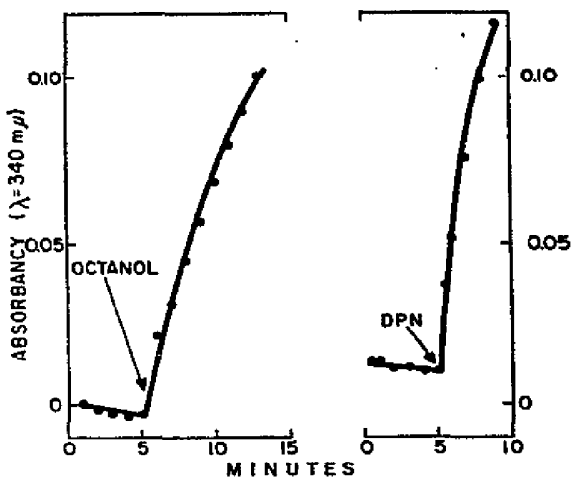

Fig. 3. DPN reduction as a function of time. As shown in the curve on the left, no increase in absorbancy at $34^{\circ} \mathrm{m} \mu$ occurred when I. $5 \mu$ moles DPN, $270 \mu$ moles potassium phosphate buffer ( $\mathrm{pH} 7.8$ ) and partially purified octanol dehydrogenase (o.63 $\mathrm{mg}$ protein) were mixed in a cuvette in a final volume of $3.0 \mathrm{ml}$ at room temperature. At the time indicated by the arrow, the solution was saturated with $n$ octanol by the addition of a small drop with stirring, resulting in rapid reduction of DPN. As thown in the curve on the right, no increase in absorbancy occurred when $0.75 \mu m o l e ~ T P N$, $270 \mu$ moles phosphate buffer $(2.7 \circ \mathrm{ml}, \mathrm{pH} 7.8$, saturated with $n$-octanol) and partially purified dehydrogenase ( $1.27 \mathrm{mg}$ of protein) were incubated in a final volume of $2.90 \mathrm{ml}$, but the addition of $0.10 \mathrm{ml}$ DPN solution ( $0.75 \mu$ mole) at the time indicated by the arrox resulted in rapid octanol oxidation as judged by DPNH formation.

An enzyme fraction containing octaldehyde dehydrogenase was prepared as follows. A crude bacterial extract $(9 \mathrm{ml})$ was heated for 10 min in a $47-49^{\circ}$ water bath. The preparation was rapidly cooled and centrifuged, and the supernatant solution was brought to $48 \%$ saturation with ammonium sulfate. The precipitate obtained upon centrifugation was dissolved in $4 \mathrm{ml}$ of o.I M phosphate buffer ( $\mathrm{pH}$ 7.0) and treated with I\% protamine sulfate (adjusted to $\mathrm{pH}$ 6.8-7.o) until no further precipitation occurred. The precipitate was removed by centrifugation, and the supernatant solution was brought to $30 \%$ saturation with $\mathrm{NH}_{4} \mathrm{SO}_{4}$. The resulting precipitate was dissolved in $0 . I \mathrm{M}$ potassium phosphate buffer ( $\mathbf{p H} 7$ ). The aldehyde dehydrogenase preparation was largely free of DPNH oxidase, octanol dehydrogenase and the enzyme system converting octane to octanol. The specificity for DPN in aldehyde oxidation is shown in Fig. 5 .

No attempts were made to establish the specificity of the octanol and octaldehyde dehydrogenases toward other alcohols or aldehydes since these enzymes were not extensively purified by the procedures described. On the other hand, it is apparent that the bacterial enzyme preparations can effect these reactions in accord with the reaction sequence proposed. 
Properties of hydrocarbon-oxidizing system

In crude bacterial extracts no added cofactors were required for the overall conversion of octane to octanoate. Charcoal-treated enzyme preparations were reduced in activity, but this was almost completely restored by the addition of either a "juice" prepared by boiling the original extract and discarding the precipitate, or a pyridine

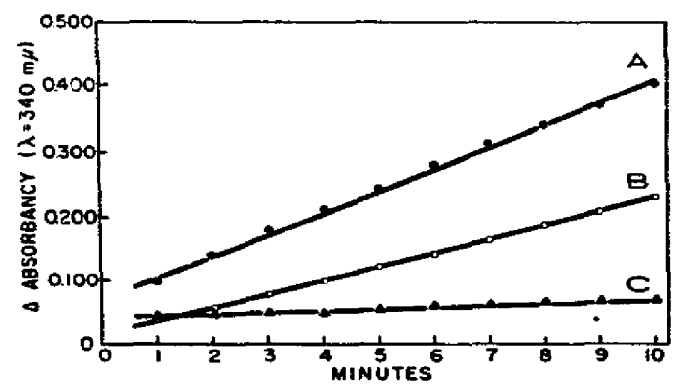

Fig. 5. Increase in absorbancy at $340 \mathrm{~m} \mu$ as a function of time. Curve $A$ indicates the rate of DPNH formation in a mixture containing $27^{\circ}$ $\mu$ moles phosphate buffer ( $\mathrm{pH} 7.8$ ), $1.5 \mu$ moles DPN, and octaldehyde dehydrogenase preparation (0.70 mig protein); octaldehyde was added as a saturated solution in $2.70 \mathrm{ml}$ of the buffer solution. The final volume was $3.0 \mathrm{ml}$. Curve $B$ indicates the rate when $0.35 \mathrm{mg}$ protein was used. Curve $C$ shows no significant reaction occurred with $0.70 \mathrm{mg}$ protein when TPN was substituted for DPN. Octaldehyde was omitted from a control cuvette in each experiment.

nucleotide. In one experiment the total counts/min recovered in octanoate with a charcoal-treated extract were as follows: no addition, I70; $3.5 \mu$ moles DPN, 900; $3.5 \mu$ moles TPNH, IIoo; both nucleotiaus, 780 . Boiled enzyme could not substitute for native enzyme.

Preliminary experiments indicate that the cell-free enzyme system prepared as described is non-particulate; for example, good activity in the overall conversion of octane to octanoate is retained in the clear supernatant solution obtained upen centrifuging an extract at $0^{\circ}$ for $60 \mathrm{~min}$ at $87000 \times g$.

\section{DIscussiox}

The results presented indicate that in the cell-free enzyme preparations employed octane is apparently metabolized via the route: octane $\rightarrow n$-octanol $\rightleftharpoons$ octaldehyde $\rightarrow$ octanoate. These findings suggest that the initial oxidative attack is at a methyl rather than a methylene carbon atom of the alkane, but do not rule out the occurrence of a more complicated sequence of reactions or the formation of ar intermediate (such as a hydro-peroxide) prior to $n$-octanol formation. It should be noted that octanoate was distinguished from heptanoate and pelargonate as well as from other acids, thereby ruling out unlikely reactions such as carboxylation of octane or loss of a $C_{1}$ unit as an initial step. The conclusion that the primary alcohol is formed is in accord with the interpretation placed by STEwART et al. ${ }^{7}$ on their identification of cetyl palmitate as the product of hexadecane oxidation in whole bacterial cultures. Other investigators have reported the accumulation of the corresponding primary alcohols from long-chain hydrocarbons in intact Pseuduinonad cultures, but without evidence for the exact structures of these products ${ }^{18,19}$. There appears to be agreement that in non-biological alkane oxidations methylene groups are more likely to undergo hydroperoxide formation than methyl groups, but regardless of the mechanism of the biological oxidation process, the ${ }^{10} \mathrm{O}$ data of STEwART et al. ${ }^{7}$ leave no doubt that atmospheric oxygen participates. 
In contrast, the studies of SENEz et al. ${ }^{10-12}$ have led to the proposal of an anaerobic pathway by which paraffins undergo dehydrogenation as the initial metabolic reaction. Their report that both DPN and pyocyanin undergo reduction by paraffins undor anaerobic conditions in cell-free "heptane dehydrogenase" preparations led to the assumption that the corresponding olefin might thereby be formed. Such a product has not been identified in cell-free preparations, but CHOUTEAU, AZOULAY AND SENEZ ${ }^{20}$ have recently reported that $\mathrm{CCl}_{4}$ extracts of $P$. aeruginosa cells exposed to heptane under anaerobic conditions contain a substance apparently identifiable as I-heptene by infrared spectrophotometry.

It would appear that purification of the enzyme systems involved is necessary to a thorough understanding of either the proposed aerobic or anaerobic routes of paraffin metabolism. A radioactive acid somewhat more polar than octanoic and stable to gentle heating with alkali or mineral acid has been found in some experiments as a product of octane oxidation in bacterial extracts ${ }^{21}$. This compound may be a direct oxidation product of octanoate, from which it is formed in higher yield than from octane. As will be described in the second paper of this series, two distinct enzyme fractions are required for the formation of octanol from octane, and studies are in progress on the possible function of each fraction in the initial attack on the hydrocarbon.

\section{ACKNOWLEDGEMENTS}

This work was supported by a grant from the National Science Foundation. The authors are indebted to Dr. J. B. DAvis for examining and providing a tentative identification of the soil Pseudomonad and to Mr. S. GREEN for technical assistance in some of the experiments described.

\section{REFERENCES}

1 C. E. ZoBrel, Advances in Enzymol., 10 (1950) 443.

2 J. B. Dayis and D. M. Updegraff, Bacteriul. Revs., i 8 (1954) 215.

3 E. Beerstecher, Jr., Petroleum Microbiology, Elsevier, Amsterdam, 1954.

- M. DWorkin and J. W. Fostek, $J$. Bacteriol., 72 (1956) 646.

5 L. R. Brown and R. J. Strawinsky, Bacteriol. Proc., (I958) 122.

- E. R. Leadbetter and J. W. Foster, Arch. Biochem. Biophys., 82 (1959) 491.

? J. E. Stewart, R. E. Kallio, D. P. Stevenson, A. C. Jones and D. O. Schissler, J. Bacteriol., 78 (1959) 441 .

B J. E. Stewart and R. E. Kallio, J. Bacteriol., 78 (1959) 726.

9 J. N. Baptist and M. J. Coon, Abstr. Am. Chem. Soc., 135th Meeting, Boston, $1959,9 \mathrm{C}$.

10 J. C. Senez and E. Azoulay, Biochim. Biophys. Acta, 47 (1961) 307.

11 E. Azoulay and J. C. Senez, Compt. Rend., 247 (19.58) 1951.

12 J. C. Senez and M. Konovaltschikoff-Mazoyer, Compt. Rend., 242 (1956) 2873.

13 M. Lee and A. C. Chandler, $J$. Bact., 4 I (194I) 373 .

14 H. C. Rilling and M. J. Coon, J. Biol. Chem., 235 (1960) 3087.

15 O. H. Lowry, N. J. Rosebrough, A. L. Fark and R. J. Randall, J. Biol. Chem., 193 (195I) 265.

16 O. Warburg and W. Christian Biochom. $Z ., 3$ Io $(194 \mathrm{I}-42) 384$.

17 G. A. Howard and A. J. P. Martin, Biochem. J., 46 (1950) 532.

18 M. T. Haydeman, Biochim. Biophys. Acta, 42 (1960) 557.

19 M. H. Proctor, Biochim. Biophy's. Acta, 42 (1960) 559.

20 J. Choutenu, E. Azoulay aNd J. C. Senez, Natiere, 194 (1962) $57^{6}$.

21 R. K. Gholson, A. Khetrry and M. J. Coon, unpublished data. 